\title{
Food standards after the BSE Inquiry report... a worrying problem for public health
}

\section{S Dealler}

\section{Lessons to be learnt after the BSE Inquiry Report}

T he population of the Earth is considered to have increased from 1.5 billion to 6 billion over the past 100 years and yet the production of food has been adequate. The racing of farming technology, genetics, chemistry, and international markets against the progressive shortage of fertile land has led to several factors. If a farmer in the UK wants to sell his potatoes to supermarkets, he is in competition with the prices from Argentina, where land and staff are cheaper. As a result, if there is a method to increase his output even by $5 \%$ then his profits soar. So, if a method appears that does just this, then the farmer must take it up. He must take short-term decision and cannot sell his produce if he does not; otherwise his rent and costs will grow past his income and he will be bankrupt. Because of this, the UK Ministry of Agriculture Fisheries and Food (MAFF) was under intense pressure to lean on the side of the producer.

In March 1996 an announcement was made in The House of Commons of a short series of cases of a new form of spongiform encephalopathy found in young people in the UK starting in 1995. At this point it was realised that the Department of Health had not been informed of the calculated risks that had been taken, or of the lack of information to justify the decisions taken by MAFF. The entire population had been put at a risk that MAFF had hoped was low.

In 1999 the UK Government (and in the media) decided that actions made by MAFF concerning bovine spongiform encephalopathy (BSE), chicken salmonellosis, listeria, microwave inadequate killing of bacteria, and E coli 157 may not have been adequate. As a result, a section of MAFF was made into a separate unit, the Food Standards Agency (FSA) which should report to government and not to MAFF. It has been now made part of the Department of Environment, Food and Rural Affairs.

In October 2000 The BSE Inquiry report ${ }^{1}$ by Lord Phillips of Worth Maltravers' Committee was released in which the reasons for the errors being made by government were described. BSE, as a fatal condition with no method of treatment was looked on as an unknown hazard to humans by MAFF and so reasonable but inadequate measures had been taken. The document explains how there was a tendency to assume safety of food methods, that there was not rapid enforcement of regulations, and that medical advice was commonly not sought. The decisions concerning BSE were made in private, research was organised and carried out in such a way that results were not released for public knowledge, and other governmental departments were only informed when this was necessary. The Spongiform Encephalopathy Advisory Committee contained members who were known to consider that BSE would not be a risk to humans and it was only asked for advice on specific questions. Any other advice could be ignored by the Agriculture Ministry. Public announcements were made by MAFF to give the impression that there was no risk from BSE despite the fact that some of its own researchers did not think this was true, and misleading information was given to the European Commission and to the media. Scientific research into the field was inadequate and only carried out under specific directives; indeed samples of tissue were refused to researchers that would not produce reassuring results. Even after the appearance of the feline spongiform encephalopathy in 1990, which suggested that BSE could not be assumed to lack risk to humans, MAFF continued to consider that this risk was minor despite damaging criticism from its own scientists, one of whom went to the Chief Veterinary Officer directly to explain why the statements to the public were misleading. He was told that he must not release any of his data to the public even if he left his job or he could be jailed for doing so.

By the time of the report over $97 \%$ of the cattle in the UK were from a herd that had had a case of BSE, on average every human in the UK will have eaten 50 meals made of the meat of an infected bovine, and the BSE risk to the populous would have been almost entirely taken. The major risk was probably in 1989 before the banning of specific offals from human food and an accurate knowledge of the total risk may not be known until after 2005 or even 2010 . $^{2}$ Indeed, total cases numbers of variant CreutzfeldtJakob disease in UK have been estimated at between 100 (now withdrawn) and 10 million. As a result the FSA statement after the report that regulations in place were adequate was almost certainly correct; it was simply too late.

One hundred years ago, if a farm chicken carried salmonella then a family might be ill. Now, the supply of chicks may be central, the supply of chicken food is from a small number of companies, and their slaughter and packing would be at a central site in thousands. So now if a link in the chain is contaminated then large numbers of people are exposed to the illness. Similarly, the progressively centralised production of agricultural chemicals means that if a mistake is made then a reasonable proportion of the population would be exposed. Information and advertising concerning food production methods can now spread rapidly. If a new chemical is found that will permit more milk produced on a farm, then instead of a method spreading slowly over many years, it will be used rapidly over Europe and America.

The FSA will be under intense pressure to maintain the balance books of farmers and companies. The economic forces in a world of increased populations will mean that the public health food risks to people from novel factors may also be progressively greater. As such the BSE Inquiry report's importance may be its requests that government bodies act openly and take notice of external advice. Without this the FSA (and its equivalents in many countries) will make mistakes and yet cannot know the chemicals and microbes that may be around the corner without independent experts, be they invited or not. As indicated in the report, if the FSA had been in charge of BSE, the agency would have needed to take long term decisions despite the immediate economic damage and should have listened to medical advice even though it was bad news. We can now understand the certainty that the FSA will have to deal with future unknown hazards. BSE has made it clear that, because of the way in which new food manufacture techniques are introduced, growing potential inadequately understood public health risks may appear but the economic pressure to take those risks will grow also.

J Epidemiol Community Health 2002;56:803

\section{Author's affiliation}

S Dealler, Burnley General Hospital, UK

Correspondence to: Dr S Dealler, Wyndhurst, Pendlehurst Street, Burnley BB 11 4RL, UK deal@airtime.co.uk

\section{REFERENCES}

1 Lord Phllips of Worth Maltravers, Bridgeman J, Ferguson-Smith M. The BSE Inquiry. London: The Stationery Office, 2000.

2 Dealler SF. Should young UK cattle be considered free of BSE or is it endemic? British Food Journal 2001;103:264-80. 